\title{
Correction to: Characteristics of ammonia gas emissions from soybean cultivation soils treated with mixed microorganisms
}

Jong-Hwan Park ${ }^{1 \dagger}$, Su-Lim Lee ${ }^{1 \dagger}$, Se-Wook Hwang ${ }^{1}$, Ju-Hyun Eom', Seong-Heon Kim², Se-Won Kang ${ }^{3}$, Ju-Sik $\mathrm{Cho}^{3}$ and Dong-Cheol Seo ${ }^{1 *}$

\section{Correction to: Appl Biol Chem (2020) 63:20} https://doi.org/10.1186/s13765-020-00503-3

The original version of this article [1], contained a mistake. The Project number is incorrect in "Acknowledgement" section.

The incorrect project number "PJ01425301" should be replaced with "PJ014253042020"

The original article has been corrected.

\section{Author details}

1 Division of Applied Life Science (BK21 Plus) \& Institute of Agriculture and Life Science, Gyeongsang National University, Jinju 52828, South Korea. ${ }^{2}$ Soil and Fertilizer Division, National Institute of Agricultural Sciences, Wanju 55365 South Korea. ${ }^{3}$ Department of Bio-Environmental Sciences, Sunchon National University, Suncheon 57922, South Korea.

Published online: 28 January 2021

\section{Reference}

1. Park JH, Lee SL, Hwang SW, Eom JH, Kim SH, Kang SW, Cho JS, Seo DC (2020) Characteristics of ammonia gas emissions from soybean cultivation soils treated with mixed microorganisms. Appl Biol Chem 63:20. https://doi.org/10.1186/s13765-020-00503-3

\section{Publisher's Note}

Springer Nature remains neutral with regard to jurisdictional claims in published maps and institutional affiliations.

\footnotetext{
*Correspondence: drseodc@gmail.com

${ }^{\dagger} J$ ong-Hwan Park and Su-Lim Lee contributed equally to this work

${ }^{1}$ Division of Applied Life Science (BK21 Plus) \& Institute of Agriculture and Life Science, Gyeongsang National University, Jinju 52828, South Korea

Full list of author information is available at the end of the article
}

SpringerOpen

(c) The Author(s) 2021. This article is licensed under a Creative Commons Attribution 4.0 International License, which permits use, sharing, adaptation, distribution and reproduction in any medium or format, as long as you give appropriate credit to the original author(s) and the source, provide a link to the Creative Commons licence, and indicate if changes were made. The images or other third party material in this article are included in the article's Creative Commons licence, unless indicated otherwise in a credit line to the material. If material is not included in the article's Creative Commons licence and your intended use is not permitted by statutory regulation or exceeds the permitted use, you will need to obtain permission directly from the copyright holder. To view a copy of this licence, visit http://creativecommons.org/licenses/by/4.0/. 